\title{
Systematic Parasitology
}

\section{an international journal}

Editor in Chief: Dr. Sheila Willmott, Winches Farm Field Station, 395 Hatfield Road, St. Albans, Herts ALA OXQ, England

SYSTEMATIC PARASITOLOGY was launched in 1979 in response to the need for a specialist international journal dealing with the systematic, taxonomic and nomenclatural aspects of parasitic organisms throughout the world.

The study of parasitic animals, many with complicated life-cycles involving two or more hosts, has long fascinated biologists but the subject is of much more than academic interest. Many of the world's most serious diseases of man, animals and plants are caused by paprasites. Mortality, long-term chronic illness, morbidity and crop losses are the result. The fact that five of the six diseases given priority in the WHO Special Programme for Research and Training in Tropical Diseases are caused by helminths and protozoans, underlines the practical importance of these groups.

Until relatively recently, identification was made mainly on morphological grounds. Now, with scanning and transmission electron microscopy, microbiochemical techniques, isoenzyme determinations and numerical taxonomy, more and more interand infraspecific variations and differences are being detected. The importance of these differences in the aetiology of disease, virulence immunogenicity and response to drugs and other chemicals used in control is recognized as of the greatest sifnificance. But in order to work successfully on all these important applied aspects, correct identification and naming of the parasites is an essential pre-requisite.

The journal publishes papers on the systematics, taxonomy and nomenclature of the Nematoda (including plant parasires), Monogenea, Digenea, Cestoda, Acanthocephala, Aspidobothria, Cestodaria, Arthropoda (parasitic copepods, hymenopterans, mites, ticks, etc.), Protozoa (parasitic groups) and parasitic genera in other groups, e.g. Mollusca, Turbellaria etc. Papers on the application of new techniques to taxonomic work are also acceptable.

In order to maintain high standards, all contributors describing new taxa are asked to state clearly where the holotype is deposited and to make paratypes available for examination by the referees. It is recognized that, in some cases, this may cause problems for the authors, but it is hoped that by adhering to this rule authors may be protected against rapid synonymization of their taxa, and the types preserved for posterity.

All contributions should be in the English language.

Volume 6 will be published in 1984 and will comprise 4 issues. The price is Dfl. 200.00 /US $\$ 80.00$ /approx. $£ 50.75$ plus Dfl. 25.00 /US $\$ 10.00$ /approx. $£ 6.25$ for postage and handling.

Private subscribers are entitled to a reduced subscription price of Dfl. $120.00 /$ US $\$$ 48.00/approx. £ 30.50 including postage and handling.

Orders should be sent to your regular supplier or to:

Kluwer Academic Publishers Group, Distribution Centre, P.O. Box 322

3300 AH Dordrecht, The Netherlands

Dr. W. Junk Publishers

P.O. Box 13713 . 2501 ES The Hague. The Netherlands

190 Old Derby Street. Hingham. MA 02043 . USA 


\section{PARASITOLOGY}

BACK VOLUMES. Vols. 1-39: Inquiries should be addressed to Wm. Dawson \& Sons Ltd, Cannon House, Folkestone, Kent. Vols. 40 onwards : quotations for parts still in print may be obtained from the Cambridge or New York offices of the Cambridge University Press.

COPYING. This journal is registered with the Copyright Clearance Center, 21 Congress Street, Salem, Mass. 01970. Organizations in the U.S.A. who are also registered with C.C.C. may therefore copy material (beyond the limits permitted by sections 107 and 108 of U.S. copyright law) subject to payment to C.C.C. of the per-copy fee of $\$ 05.00$. This consent does not extend to multiple copying for promotional or commercial purposes. Code 0031-1820/84/0080-0001 \$05.00.

ISI Tear Service, 3501 Market Street, Philadelphia, Pennsylvania 19104, U.S.A., is authorized to supply single copies of separate articles for private use only.

FOR ALL OTHER USE, permission should be sought from the Cambridge or New York offices of the Cambridge University Press.

CLAIM S for missing issues can only be considered if made immediately after receipt of the subsequent issue.

A Dvertising. Details of advertising in Parasitology may be obtained from the publisher. 


\title{
PARASITOLOGY
}

\author{
Volume 89, Part 1, August 1984
}

\section{GONTENTS}

PAGE

Pittilo, R. M. and BALL, S. J. Electron microscopy of Eimeria acervulina macrogametogony and oocyst wall formation

Chapman, H. D. Eimeria tenella: experimental development of resistance to monensin in the chicken

Panton, Lindsey J., Knowles, G. and Walliker, D. Studies of antigens in Plasmodium yoelii. I. Antigenic differences between parasite lines detected by crossed immunoelectrophoresis

Panton, Lindsey J., Knowles, G. and Wal.tKer, D. Studies of antigens in Plasmodium yoelii. II. Inheritance and recombination of antigenic characters

Richards, K. Sylvia, Arme, C. and Bridges, JANine F. Echinococcus granulosus equinus: variation in the germinal layer of murine hydatids and evidence of autophagy

BARry, J. D. and Gathuo, H. Antigenic variation in Trypanosoma vivax: isolation of a serodeme

Crabtree, Jean E. and Wilson, R. A. Schistosoma mansomi: cellular reactions to challenge infections in the cheek pouch skin of chronically infected Chinese hamsters

Leitch, B., Probert, A. J. and Runham, N. W. The ultrastructure of the tegument of adult Schistosoma haematobium

Anderson, R. M. and Crombie, Jenny. Experimental studies of age-prevalence curves for Schistosoma mansoni infections in populations of Biomphalaria glabrata

BIRD, A. F. Growth and moulting in nematodes: moulting and development of the hatched larva of Rotylenchulus reniformis

Craig, P. S. Circulating antigens, antibodies and immune complexes in experimental Taenia pisiformis infections of rabbits

Crompton, D. W. T. and Ward, P. F. V. Selective metabolism of L-serine by Moniliformis (Acanthocephala) in vitro

Wedrychowicz, H., Maclean, J. M. and Holmes, P. H. Secretory IgA responses in rats to antigens of various developmental stages of Nippostrongylus brasiliensis

Scott, Marilyn E. and Anderson, R. M. The population dynamics of Gyrodactylus bullatarudis (Monogenea) within laboratory populations of the fish host Poecilia reticulata

McCallum, H. I. and Anderson, R. M. Systematic temporal changes in host susceptibility to infection: demographic mechanisms

The Pitt Building, Trumpington Street, Cambridge CB2 1RP

32 East 57th Street, New York, N.Y. 10022, U.S.A.

10 Stamford Road, Oakleigh, Melbourne 3166, Australia

Printed in Great Britain at the University Press, Cambridge 